\title{
Comparison of Polycyclic Aromatic Hydrocarbon (PAHs) concentrations in urban and natural forest soils in the Atlantic Forest (São Paulo State)
}

\author{
CHRISTINE BOUROTTE ${ }^{1,2}$, MARIA CRISTINA FORTI ${ }^{1,3}$, YVES LUCAS ${ }^{4}$ and ADOLPHO J. MELFI ${ }^{1,5}$ \\ ${ }^{1}$ NUPEGEL/USP, Av. Pádua Dias, 11, 13410-900 Piracicaba, SP, Brasil \\ ${ }^{2}$ Instituto de Geociências, Departamento de Geologia Sedimentar e Ambiental, Universidade de São Paulo \\ Rua do Lago, 562, Cidade Universitária, 05508-900 São Paulo, SP, Brasil \\ ${ }^{3}$ Instituto Nacional de Pesquisas Espaciais (INPE), Caixa Postal 515, 12245-970 São José dos Campos, SP, Brasil \\ ${ }^{4}$ Processus de Transfert et d'Echange dans l'Environnement (PROTEE), Université du Sud Toulon-Var \\ BP20132, 83957 La Garde Cedex, France \\ ${ }^{5}$ Departamento de Ciência do Solo da Escola Superior de Agricultura Luiz de Queiroz, Universidade de São Paulo \\ ESALQ/USP, Caixa Postal 09, 13418-900 Piracicaba, SP, Brasil \\ Manuscript received on January 14, 2008; accepted for publication on August 26, 2008; \\ contributed by ADOLPHO J. MELFI*
}

\begin{abstract}
Studies about pollution by Polycyclic Aromatic Hydrocarbons (PAHs) in tropical soils and Brazil are scarce. A study was performed to examine the PAHs composition, concentrations and sources in red-yellow Oxisols of remnant Atlantic Forest of the São Paulo State. Sampling areas were located in an urban site (PEFI) and in a natural one (CUNHA). The granulometric composition, $\mathrm{pH}$, organic matter content and mineralogical composition were determined in samples of superficial soils. The sum of PAHs ( HPAs) was 4.5 times higher in the urban area than in the natural one. Acenaphthylene, acenaphthene, fluorene, phenanthrene and fluoranthene have been detected in the soils of both areas and presented similar concentrations. Acenaphthene and fluorene were the most abundant compounds. Pyrene was twice more abundant in the soils of natural area $\left(15 \mu \mathrm{g} \cdot \mathrm{kg}^{-1}\right)$ than of the urban area and fluoranthene was the dominant compound (203 $\left.\mu \mathrm{g} \cdot \mathrm{kg}^{-1}\right)$ in urban area (6.8 times higher than in the natural area). Some compounds of higher molecular weight, which are tracers of vehicular emissions showed significant concentrations in urban soils. Pyrene represented $79 \%$ of $\Sigma$ PAHs whereas it has not been detected in natural soils. The results showed that forest soils in urban area are characterized by the accumulation of high molecular weight compounds of industrial and vehicular origin.
\end{abstract}

Key words: Atlantic Forest, polycyclic aromatic hydrocarbons, PAHs, tropical forest, tropical soils, urban soils.

\section{INTRODUCTION}

The Polycyclic Aromatic Hydrocarbons (PAHs) are chemicals with carcinogenic and mutagenic potential and are mainly derived from incomplete combustion processes of stationary (industries, incineration, heating) as well as mobile sources (vehicular emissions). The contribution of natural source of PAHs is limited, be-

\footnotetext{
*Member Academia Brasileira de Ciências

Correspondence to: Adolpho José Melfi

E-mail: ajmelfi@usp.br
}

ing restricted to forest burning (Gonzalesvila et al. 1991, Jenkins et al. 1996). The low molecular weight PAHs (2 and 3 aromatic rings) are found preferentially in the gas phase, while the compounds of larger molecular weight (4 to 6 aromatic rings) are adsorbed on the surface of suspended particles.

The high demand for fossil fuels and its combustion as a consequence of the high urbanization rate with the industrial development and the increase in the population and vehicular fleet during the last decades caused a rise 
in the emission of PAHs to the atmosphere. These compounds, as well as many other contaminants, are emitted directly into the atmosphere, and then submitted to wet and dry deposition. Soils are a primary sink for contaminants due to their capacity to retain hydrophobic chemicals (Wild and Jones 1995). Their accumulation in urban soils degrades the soil quality and represents a risk for humans and ecosystems.

The studies of the behavior of PAHs have begun in the seventies, but their results cannot be fully extrapolated to tropical regions because of the differences in climate. As Wilcke et al. (2003) emphasized, "in the last two decades, much research work has produced an improved understanding of the sources and fate of the hazardous PAHs in temperate environments. In contrast, little is known about the sources and fate of PAHs in tropical environments".

In Brazil, studies related with PAHs have recently been conducted to investigate their presence in the atmosphere of urban centers such as São Paulo city (Bourotte et al. 2005, Vasconcellos et al. 2003, Martinis et al. 2002) and Rio de Janeiro city (Santos et al. 2002, Fernandes et al. 2002, Azevedo et al. 1999, Miguel and Pereira 1989, Miguel and Andrade 1989, Daisey et al. 1987). Very few studies were conducted regarding PAHs in soil (Wilcke et al. 2003, 2004).

Thus, the objectives of this work were to characterize the composition and identify the distribution pattern of PAHs in two contrasting tropical soils: an urban forest soil, located in a remnant forest inside the São Paulo city (PEFI), and a natural forest soil located in the Atlantic Forest and considered as non-polluted reference (CUNHA).

\section{MATERIALS AND METHODS}

\section{SAMPLING LOCATION}

The Metropolitan Region of São Paulo (MRSP) with an approximate area of $8,000 \mathrm{~km}^{2}$ is located in the southeastern part of Brazil $\left(23^{\circ} \mathrm{S}\right.$ and $\left.46^{\circ} \mathrm{W}\right)$, has about 17 millions inhabitants distributed over an urbanized area of about $1,747 \mathrm{~km}^{2}$ and is the third largest urban agglomeration in the world. The MRSP has about 2,000 industrial plants and 7.2 millions vehicles $(20 \%$ of the national fleet) which are responsible for the emission of $98 \%$ of $\mathrm{CO}, 97 \%$ of hydrocarbons, $97 \%$ of $\mathrm{NO}_{\mathrm{x}}, 52 \%$ of particulate matter and $55 \%$ of $\mathrm{SO}_{\mathrm{x}}$. Diesel vehicles represent $6.5 \%$ of the total fleet and their emissions constitute $18,4 \%$ of total vehicular emissions of hydrocarbons and $77 \%$ of particulate matter emissions, corresponding to 70,600 and 19,700 tons, respectively (CETESB 2006).

The chosen areas for integrated monitoring are located in the Parque Estadual das Fontes do Ipiranga PEFI (urban) and in the Parque Estadual da Serra do Mar - Núcleo Cunha/Indaiá - CUNHA (natural). The first one is under strong anthropic influence and the second one is not under that influence. The location of the two areas is shown in Figure 1.

\section{Urban Forest - PEFI}

The study area is located in the Southeastern region of the São Paulo City County between parallels $23^{\circ} 38^{\prime} 08^{\prime \prime}$ and $23^{\circ} 40^{\prime} 18^{\prime \prime} \mathrm{S}$ and meridians $46^{\circ} 36^{\prime} 48^{\prime \prime}$ e $46^{\circ} 38^{\prime} 00^{\prime \prime} \mathrm{W}$ and $50 \mathrm{~km}$ from sea shore. This site is located in a remnant part of the Atlantic Forest forming a 526 ha Reserve Park named PEFI (Parque Estadual das Fontes do Ipiranga) entirely located within the urban area, in the neighborhood of the largest industrial region of South America, and thus submitted to high urban pollutants impact. This urban forest has a large portion of natural vegetation still preserved. Because of the extension of its vegetation cover, PEFI is recognized as an outstanding area of São Paulo city for its environment and social aspect (Bicudo et al. 2002). PEFI's climate is influenced by extra-tropical (e.g. frontal systems) and tropical (e.g. squall lines and convergence zones) systems. Based on climatological time series of 67 years (1933-1999) the mean annual rainfall is $1368 \mathrm{~mm}$ with a dry period from May until August. The mean temperature for the coldest month is $15^{\circ} \mathrm{C}$ (July) and for the two hottest months are $21-22^{\circ} \mathrm{C}$ (January-February). The chosen catchments have a drainage area of 21 ha with $0.044 \mathrm{~m} . \mathrm{m}^{-1}$ of declivity. It is on crystalline rocks with gneisses and secondarily micaschists. Over these rocks it is found clay, sand and gravels belonging to the São Paulo Formation. The topography presents undulated forms with heights between $770 \mathrm{~m}$ and $825 \mathrm{~m}$ being part of the central ridge hills of the São Paulo city. The soils are red-yellow latossol (Brazilian soil Classification) derived from phyllite, schist and granit-gnaissics rocks. Chemically these soils are poor, with low cation exchange capacity, acidic, 


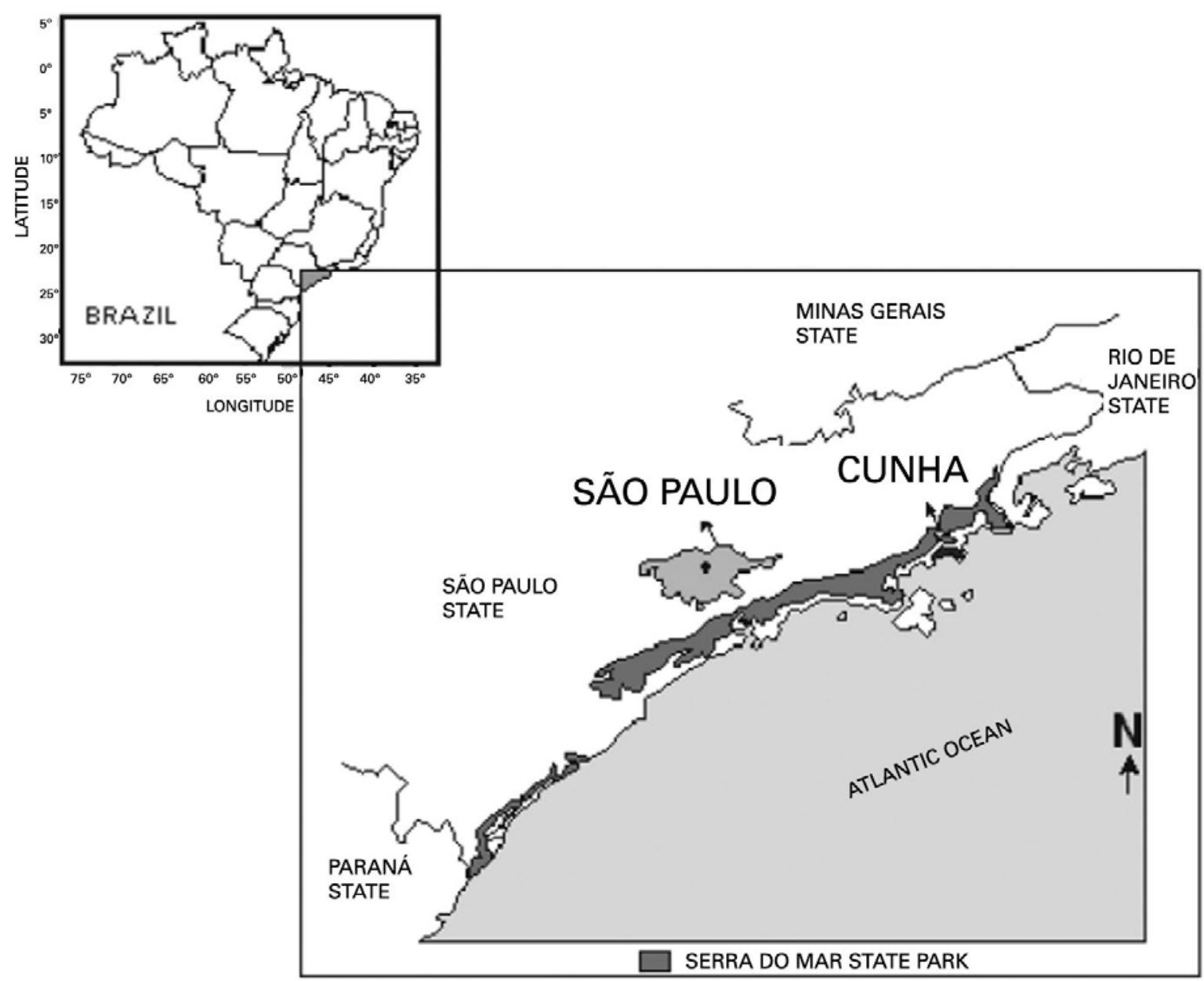

Fig. 1 - Localization map of the two study areas.

with toxic levels of aluminum and potential characteristics for phosphorus fixation (Struffaldi-De-Vuono et al. 1984).

\section{Natural Forest - CUNHA}

The Cunha-Indaiá Núcleo is located between the parallels $23^{\circ} 13^{\prime} 28^{\prime \prime}$ and $23^{\circ} 16^{\prime} 10^{\prime \prime} \mathrm{S}$ and meridians $45^{\circ} 02^{\prime} 53^{\prime \prime}$ e $45^{\circ} 05^{\prime} 15^{\prime \prime} \mathrm{W}$ in the Northern portion of the State of São Paulo, $250 \mathrm{~km}$ from the Metropolitan Area of São Paulo, within the Serra do Mar State Park and hosts Eng. Agr. Walter Emmerich Forest Hydrology Laboratory of the Institute of Forestry of the State of São Paulo. It is about $15 \mathrm{~km}$ apart from the Atlantic Ocean at an altitude of $1050 \mathrm{~m}$ from sea level. It covers an area of 2,854 ha with hills and small valleys. The area is mainly covered with a primary forest named Atlantic Forest. A secondary forest is found on abandoned pasture or crops on the slopes. Pasture and bamboos cover the alluvial zones (Cicco et al. 1987). The mean maximum and minimum temperatures are $26^{\circ} \mathrm{C}$ and $16^{\circ} \mathrm{C}$ respectively. The mean annual rainfall is $1500 \mathrm{~mm}$ with the main rainy period being from September until April and the driest one from May until August. This region has a moist tropical climate. The geologic formation in this region belongs to the Brazilian crystalline complex of Pre-Cambrian with granites, gneisses, crystalline schists and diabase rocks from the Mesozoic age. The soils are developed on Pre-Cambrian granite, gneiss and schist; they are classified as red-yellowish Oxisols. The highlands portion have topography composed of low hills with marked declivity and rounded tops at intermediate heights and at the valleys the inclinations have low gradient around 10 to 20 degrees and the drainage density is low with undulated landscape. 


\section{SOIL SAMPLING AND PREPARATION}

For each sampling point, three sub-samples were taken and mixed in order to obtain a bulk sample. In both sites, sampling was realized during winter of 2000 at the following depths: $0-5 \mathrm{~cm}, 5-10 \mathrm{~cm}$ and $10-20 \mathrm{~cm}$. Samples were sieved to $<2 \mathrm{~mm}$, kept in aluminum foils and plastic hermetic bags and stored in freezer until analysis. Part of the samples was sieved at 105 meshes for powder $\mathrm{X}$-Ray diffraction analyses and $\mathrm{pH}$ determination was done on bulk, non sieved samples.

Granulometry was performed by sedimentometry. Carbon content was measured with a Shimadzu TOC5000 equipment, and soil mineralogy was investigated by powder X-Ray diffraction.

\section{EXTRACTION AND PAHS ANALYSIS}

PAHs concentrations were obtained by CG-MS after a soxhlet extraction of soil samples $(20 \mathrm{~g})$ with $250 \mathrm{ml}$ of dichloromethane during $24 \mathrm{~h}$. After concentration of the extracts by evaporation with a rotary evaporator and a gentle flux of $\mathrm{N}_{2}$, samples were submitted to a purification stage by using SPE cartridges (SUPELCO).

The analysis of 16 PAHs (16 US EPA priority PAHs) was carried out in a gas chromatograph (Hewlett Packard 6890) system connected to a Mass Spectrometer (5972A). The separation of the compounds was carried out through a capillary column RTX 5Sil-MS (Restek) of $30 \mathrm{~m}$ length, $0.25 \mathrm{~mm}$ of internal diameter and $0.25 \mu \mathrm{m}$ of film thickness using Helium as the carrier gas. The oven initial temperature $\left(50^{\circ} \mathrm{C}\right)$ was kept during 1 minute and afterwards, with a rate of $10^{\circ} \mathrm{C} / \mathrm{min}$ the temperature was raised to $280^{\circ} \mathrm{C}$ and kept by 5 min and finally with a rate of $8^{\circ} \mathrm{C} / \mathrm{min}$ the temperature reached $310^{\circ} \mathrm{C}$ and maintained by $10 \mathrm{~min}$. The analytical quality control was performed using blanks and calibration curves with 6 points $\left(2.0,1.0,0.4,0.2,0.1\right.$ e $\left.0.04 \mathrm{mg} . \mathrm{L}^{-1}\right)$ as well as with certified standards from Supelco (EPA610) and Restek. The validation of this protocol was carried out through the analysis of certified reference material (Urban Dust NIST SRM 1649a). As recovery values were low for naphthalene, the obtained values were discarded. The PAHs quantified were: acenaphthylene (ACY), acenaphthene (ACE), fluorene (FLU), phenanthrene (PHE), anthracene (ANT), fluoranthene (FLT), pyrene (PYR), benzo(a)anthracene (BaA), chrysene
(CRY), benzo(b,k)fluoranthene (BbkF), benzo(a)pyrene (BaP), indeno(1,2,3-cd)pyrene (IND), dibenz(a,h)anthracene (DahA) and benzo(ghi)perylene (BghiP).

\section{RESULTS AND DISCUSSION}

\section{SOIL CHARACTERISTICS}

The study was limited to the upper soil horizons which interact with atmosphere. In Tables I and II, the descriptive morphology of soil profile is presented for CUNHA and PEFI, respectively. The mineralogical composition, determined by powder X-Ray Diffraction, is very similar in both CUNHA and PEFI soils and typical of tropical soils. Physico-chemical characteristics of both soil profiles are presented in Table III. The CUNHA soil shows a sandy clay texture, near to the limit with clay texture. The PEFI soil is slightly sandier. The low carbon content of the $0-5 \mathrm{~cm}$ of the PEFI profile is likely due to anthropic reworking. For both soil profiles, $\mathrm{pH}$ values are typical of acidic tropical soils.

TABLE I

Morphological description of soil in Cunha sampling site.

\begin{tabular}{c|l}
\hline Depth $(\mathrm{cm})$ & \multicolumn{1}{c}{ Description } \\
\hline $0-5$ & $\begin{array}{l}\text { Homogenous dark brown, porous, crumb structure, } \\
\text { high amount of graminaceous roots. }\end{array}$ \\
\hline $5-10$ & $\begin{array}{l}\text { Heterogeneous color due to brown patches, struc- } \\
\text { ture from crumb to subangular blocky. Porosity } \\
\text { decreasing with depth. High biological activity. }\end{array}$ \\
\hline $10-40$ & $\begin{array}{l}\text { Towards depth brown patches progressively turn } \\
\text { strong brown and occupy higher volume. Brown } \\
\text { patches from filled fauna and root pipes. Decreas- } \\
\text { ing of the amount of roots. }\end{array}$ \\
\hline $40-60$ & $\begin{array}{l}\text { Strong brown, angular blocky structure with mi- } \\
\text { croaggregated sub-structure, more friable than up- } \\
\text { per horizons. }\end{array}$ \\
\hline $60-100$ & $\begin{array}{l}\text { Reddish-yellow, massive structure with microag- } \\
\text { gregated sub-structure, fragile. }\end{array}$ \\
\hline
\end{tabular}

\section{PAHS SOIL CONCENTRATIONS AND SOURCES}

PAHs concentrations integrated in the $0-20 \mathrm{~cm}$ topsoil horizons for both soils different depths are presented in Table IV. The mean concentration of the total PAHs ( $\Sigma$ PAHs) for all profile was $180 \mu \mathrm{g} \cdot \mathrm{kg}^{-1}$ in CUNHA and $818 \mu \mathrm{g} \cdot \mathrm{kg}^{-1}$ in PEFI. The $\Sigma$ PAHs concentration was 4,5 times higher in the urban soil than in the natural one. According to the classification of soil contamination by PAHs established by Maliszewska-Kordybach 
TABLE II

Morphological description of soil in PEFI sampling site.

\begin{tabular}{c|l}
\hline Depth $(\mathrm{cm})$ & \multicolumn{1}{c}{ Description } \\
\hline $0-5$ & $\begin{array}{l}\text { Homogenous dark brown structure, high amount } \\
\text { of graminaceous roots. }\end{array}$ \\
\hline $5-10$ & $\begin{array}{l}\text { Dark brown, clean quartz grains, some hard red } \\
\text { ferruginous nodules, porous, crumb structure, high } \\
\text { amount of graminaceous roots. }\end{array}$ \\
\hline $10-30$ & $\begin{array}{l}\text { Heterogeneous color due to brown patches, some } \\
\text { small hard red ferruginous nodules, black patches } \\
\text { due to charcoal grains from 10 to 20 cm, clean } \\
\text { quartz grains, subangular blocky structure with } \\
\text { microaggregated substructure. Decreasing of the } \\
\text { amount of roots. }\end{array}$ \\
\hline $30-60$ & $\begin{array}{l}\text { Strong brown with brownish-yellow patches, mas- } \\
\text { sive structure with microaggregated substructure, } \\
\text { more compact than the upper horizon, some soft } \\
\text { red ferruginous nodules. }\end{array}$ \\
\hline $60-100$ & $\begin{array}{l}\text { Strong brown, medium and coarse quartz gravels, } \\
\text { massive structure with microaggregated substruc- } \\
\text { ture, some soft red ferruginous nodules. }\end{array}$ \\
\hline
\end{tabular}

TABLE III

Physico-chemical characteristics of Cunha and PEFI soil profiles.

\begin{tabular}{c|c|c|c|c|c}
\hline $\begin{array}{c}\text { Depth } \\
(\mathrm{cm})\end{array}$ & $\begin{array}{c}\text { Total sand } \\
(\%)\end{array}$ & $\begin{array}{c}\text { Silt } \\
(\%)\end{array}$ & $\begin{array}{c}\text { Fine } \\
\text { fraction } \\
(<2 \mu \mathrm{m}) \\
(\%)\end{array}$ & $\begin{array}{c}\mathrm{C} \\
(\%)\end{array}$ & $\mathrm{pH}$ \\
\hline \multicolumn{6}{|c|}{ CUNHA } \\
\hline $00-15$ & 45 & 9 & 46 & 2.86 & 4.15 \\
\hline $10-20$ & 52 & 8 & 40 & 1.76 & 4.70 \\
\hline $20-30$ & 49 & 9 & 42 & 1.76 & 4.64 \\
\hline $30-40$ & 47 & 9 & 44 & - & 4.58 \\
\hline $40-60$ & 47 & 7 & 46 & 1.52 & 4.54 \\
\hline $60-80$ & 45 & 9 & 46 & 1.34 & 4.52 \\
\hline $80-100$ & 45 & 9 & 46 & 1.27 & 4.43 \\
\hline \multicolumn{7}{|c|}{ PEFI } \\
\hline $00-05$ & 56 & 4 & 40 & 1.86 & 5.09 \\
\hline $05-10$ & 54 & 4 & 42 & 2.32 & 4.85 \\
\hline $10-20$ & 52 & 6 & 42 & 2.18 & 4.86 \\
\hline $20-30$ & 49 & 9 & 42 & 1.95 & 4.87 \\
\hline $30-40$ & 52 & 6 & 42 & 1.62 & 4.78 \\
\hline $40-60$ & 50 & 4 & 46 & 1.41 & 4.75 \\
\hline
\end{tabular}

(1996) considering a total of 16 PAHs, CUNHA soil is not contaminated $\left(<200 \mu \mathrm{g} \cdot \mathrm{kg}^{-1}\right)$ whereas PEFI soil can be considered as contaminated since the obtained value for $\Sigma$ PAHs ranged between 600 and $1000 \mu \mathrm{g} \cdot \mathrm{kg}^{-1}$.

The studies assessing the environmental contami- nation by PAHs in natural or urban soils pointed out that the predominant compounds are principally associated with traffic emission sources and additionally to minor sources such as industrial processes and domestic heating. Compounds of lower molecular weight such as ACY, ACE, FLU, PHE and PYR were detected with similar concentrations in CUNHA and PEFI soils. ANT, however, was under the limit of detection in both soils. Compounds of higher molecular weight, such as BaA, CRY, B(bk)F, BaP, IND and BghiP were under the limit of detection in CUNHA but with significant concentrations in PEFI, over $45 \mu \mathrm{g} \cdot \mathrm{kg}^{-1}$. FLT, which has an intermediate molecular weight, was detected in CUNHA (30 $\mu$ g. $\left.\mathrm{kg}^{-1}\right)$ but exhibited a very higher concentration in PEFI ( $\left(203 \mu \mathrm{g} \cdot \mathrm{kg}^{-1}\right)$.

In CUNHA, ACE and FLU were the most abundant compounds which accounted for $50 \%$ of the $\Sigma$ PAHs, the remaining 50\% being due to ACY, PHE, FLT and PYR. Some studies suggested that low molecular weight PAHs are likely to be naturally produced in poorly-anthropized areas in Brazil (Wilcke et al. 2003). Natural sources are thus possible to explain the low molecular weight PAHs in the CUNHA soil. In PEFI, FLT was the dominant compound and contributed to $25 \%$ of the $\Sigma$ PAHs. The other most abundant compounds were BghiP, BbkF and $\mathrm{BaP}$ which are typical tracers for fossil fuel combustion and contributed on $33 \%$ of the $\Sigma$ PAHs.

The combustion derived PAHs (FLT, PYR, CRY, BbkF, BaA, BaP, IND and BghiP) accounted for $80 \%$ and $25 \%$ of the $\Sigma$ PAHs in the PEFI soil and the CUNHA soil, respectively. The carcinogenic group (BbkF, BaA, CRY,BaP, IND and DBahA) accounted for $42 \%$ of the $\Sigma$ PAHs in the PEFI soil, while this group was not detected in CUNHA.

The repartition pattern of the PAHs in the PEFI soil is similar to patterns observed in other urban areas, as for example in New Orleans, notwithstanding the higher $\Sigma$ PAHs in New Orleans (Fig. 2).

Some studies also showed that PAHs concentrations in soil correlate with PAHs levels in the atmosphere (Wilcke 2000). A recent study in the São Paulo city showed high concentrations of PAHs in the atmosphere which can promote a continuous flux of PAHs from the atmosphere to the soils as they are still emitted by primary combustion sources (Bourotte et al. 2005). Some 


\section{TABLE IV}

PAHs concentration values (in $\mu$ g. $\mathrm{kg}^{-1}$ ) in Cunha and PEFI soils integrated in the $0-20 \mathrm{~cm}$ topsoil horizons. ( $<D L$ : lower than detection limit).

\begin{tabular}{|c|c|c|c|c|c|}
\hline \multirow{2}{*}{\multicolumn{2}{|c|}{ Compounds }} & \multicolumn{2}{|c|}{ CUNHA } & \multicolumn{2}{|c|}{ PEFI } \\
\hline & & \multirow{2}{*}{$\begin{array}{c}\mu \mathrm{g} \cdot \mathrm{kg}^{-1} \\
22,5\end{array}$} & \multirow{2}{*}{$\begin{array}{l}\% \\
13\end{array}$} & \multirow{2}{*}{$\frac{\mu \mathrm{g} \cdot \mathrm{kg}^{-1}}{37,5}$} & \multirow{2}{*}{$\begin{array}{c}\% \\
5 \\
\end{array}$} \\
\hline Acenaphthylene & $\mathrm{ACY}$ & & & & \\
\hline Acenaphthene & $\mathrm{ACE}$ & 45,0 & 25 & 45,0 & 6 \\
\hline Fluorene & FLU & 45,0 & 25 & 45,0 & 6 \\
\hline Phenanthrene & PHE & 22,5 & 13 & 37,5 & 5 \\
\hline Anthracene & ANT & $<\mathrm{DL}$ & 0 & $<\mathrm{DL}$ & 0 \\
\hline Fluoranthene & FLT & 30,0 & 17 & 203,0 & 25 \\
\hline Pyrene & PYR & 15,0 & 8 & 7,5 & 1 \\
\hline Benzo(a)anthracene & $\mathrm{BaA}$ & $<\mathrm{DL}$ & 0 & 52,5 & 6 \\
\hline Chrysene & CRY & $<\mathrm{DL}$ & 0 & 75,0 & 9 \\
\hline Benzo(bk)fluoranthene & $\mathrm{B}(\mathrm{bk}) \mathrm{F}$ & $<\mathrm{DL}$ & 0 & 90,0 & 11 \\
\hline Benzo(a)pyrene & $\mathrm{BaP}$ & $<\mathrm{DL}$ & 0 & 82,5 & 10 \\
\hline Indeno(1,2,3-cd)pyrene & IND & $<\mathrm{DL}$ & 0 & 45,0 & 6 \\
\hline Dibenz(a,h)anthracene & $\mathrm{D}(\mathrm{ah}) \mathrm{A}$ & $<\mathrm{DL}$ & 0 & $<\mathrm{DL}$ & 0 \\
\hline Benzo(ghi)perylene & BghiP & $<\mathrm{DL}$ & 0 & 97,5 & 12 \\
\hline$\Sigma$ PAHs & & 180 & 100 & 818 & 100 \\
\hline
\end{tabular}

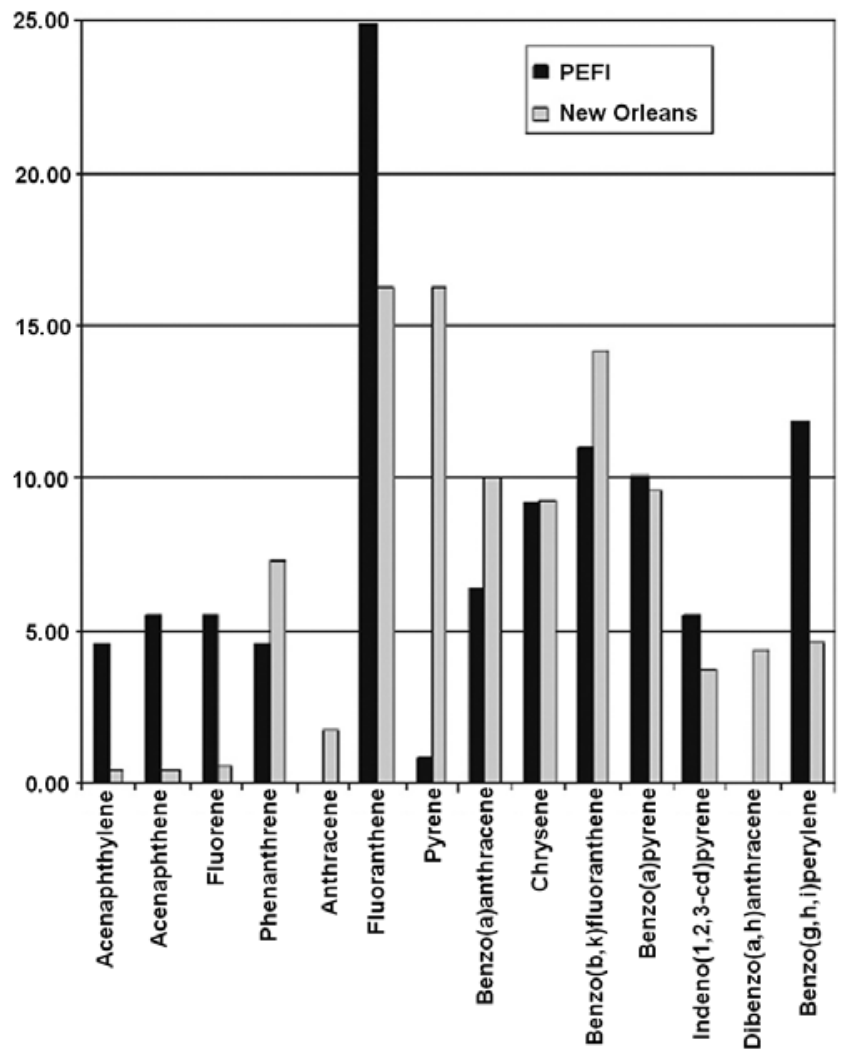

Fig. 2 - Individual contribution of PAH compounds for PEFI soil (this study) and New Orleans urban soils (Mielke et al. 2004) (values in \% of the $\Sigma$ PAHs). 
TABLE V

Total PAHs mean concentrations in soil $\left(\right.$ in $\left.\mu \mathrm{g} \cdot \mathrm{kg}^{-1}\right)$ in other countries of the world $\left({ }^{*}\right.$ median value).

\begin{tabular}{|c|c|c|c|c|c|}
\hline Location & Area & $\begin{array}{l}\text { Number } \\
\text { of PAHs }\end{array}$ & $\begin{array}{c}\text { Concentration } \\
\left(\mu \mathrm{g} \cdot \mathrm{kg}^{-1}\right)\end{array}$ & $\begin{array}{c}\text { Sampling } \\
\text { depth }\end{array}$ & Reference \\
\hline \multirow{2}{*}{ São Paulo } & Urban & \multirow{2}{*}{14} & 818 & \multirow{2}{*}{$0-20 \mathrm{~cm}$} & \multirow{2}{*}{ This study } \\
\hline & Natural & & 180 & & \\
\hline Bangkok & Urban & 20 & 129.2 & $0-5 \mathrm{~cm}$ & Wilcke et al. 1999 \\
\hline \multirow{6}{*}{ Brazil } & Amazon (Terra Firme) & \multirow{6}{*}{20} & 145 & \multirow{6}{*}{$0-10 \mathrm{~cm}$} & \multirow{6}{*}{ Wilcke et al. 2003} \\
\hline & Amazon (Igapó) & & 38 & & \\
\hline & Pantanal & & 68 & & \\
\hline & Cerrado central & & 17 & & \\
\hline & Mata Atlântica & & 115 & & \\
\hline & Caatinga & & 23 & & \\
\hline \multirow{5}{*}{ France (Seine Basin) } & Forest (Forest of Bretonne) & \multirow{5}{*}{14} & 940 & \multirow{5}{*}{$3-10 \mathrm{~cm}$} & \multirow{5}{*}{ Motelay-Massei et al. 2004} \\
\hline & Natural (Honfleur) & & 450 & & \\
\hline & Suburban (Harfleur) & & 1670 & & \\
\hline & Urban (Rouen) & & 2780 & & \\
\hline & Industrial (Oissel) & & 3390 & & \\
\hline \multirow{3}{*}{ Spain (Tarragona County) } & Unpolluted & \multirow{3}{*}{16} & 112 & \multirow{3}{*}{$0-3 \mathrm{~cm}$} & \multirow{3}{*}{ Nadal et al. 2004} \\
\hline & Residential & & 736 & & \\
\hline & Industrial & & 1102 & & \\
\hline \multirow{2}{*}{ USA (New Orleans) } & Suburban & \multirow{2}{*}{16} & $731^{*}$ & \multirow{2}{*}{$2.5 \mathrm{~cm}$} & \multirow{2}{*}{ Mielke et al. 2004} \\
\hline & Inner city & & $2927 *$ & & \\
\hline Korea & Agricultural soils & 16 & $158^{*}$ & & Nam et al. 2003 \\
\hline China (Tianjin) & Industrial & 16 & 818.2 & & Wang et al. 2003 \\
\hline Japan (Tokushima) & Urban & 13 & 610.6 & & Yang et al. 2002 \\
\hline \multirow{3}{*}{ Estonia } & Rural & \multirow{3}{*}{11} & $233-770$ & \multirow{3}{*}{$0-10 \mathrm{~cm}$} & \multirow{3}{*}{ Trapido 1999} \\
\hline & Urban (Tallinn) & & 2240 & & \\
\hline & Industrial (Kohtla-Järve) & & 12390 & & \\
\hline \multirow{2}{*}{ Norway } & Central region & \multirow{2}{*}{9} & 69 & \multirow{2}{*}{$0-5 \mathrm{~cm}$} & \multirow{2}{*}{ Aamot et al. 1996} \\
\hline & Southeastern region & & 527 & & \\
\hline Poland & Silesia region & 16 & $264(28-2447)$ & $0-15 \mathrm{~cm}$ & Maliszewska-Kordybach 1996 \\
\hline Australia (Brisbane) & Suburban & 16 & 471 & $0-5 \mathrm{~cm}$ & Pathirana et al. 1994 \\
\hline Austria (Linz) & Industrial & 18 & 1450 & & Weiss et al. 1994 \\
\hline
\end{tabular}

markers are indicative of combustion sources: ratio between PAHs such as PHE/ANT, FLT/PYR, BaP/BghiP, $\mathrm{BaA} / \mathrm{CRI}$ or IND/BghiP, are characteristic of pyrogenic origin such as motor vehicle exhausts, heavy industrial emissions, biomass burning, etc. (Bourotte et al. 2005). The values obtained in this study indicated PAHs sources associated with gasoline vehicle emissions or fossil fuels combustion by industry.

PAHs levels reported in the literature from soils of urban and natural areas are presented in Table V. The $\Sigma$ PAHs observed in Cunha is slightly higher than others values from poorly-anthropized areas from Brazil (Wilcke et al. 2003) or other countries (Nadal et al. 2004, Nam et al. 2003, Aamot et al. 1996). This could indicate the beginning of a contamination in the Cunha area.
The values reported in Table $\mathrm{V}$ also support that urban environments present significantly higher PAHs concentrations in relation to natural ones. We must point out that most of these studies are related with urban soils of temperate climates of North Hemisphere and that studies performed in Tropical regions are yet scarce. Although analytical methods, number of quantified compounds and soil characteristics vary among theses different studies, tropical soils presented lower concentrations than soils of temperate climates, except for New Orleans. Total PAHs concentrations observed in PEFI soils are lower than the ones reported for industrial soils by MotelayMassei et al. (2003) for Oissel soils (3390 $\left.\mu \mathrm{g} \cdot \mathrm{kg}^{-1}\right)$, Nadal et al. (2004) for Tarragona soils (1102 $\left.\mu \mathrm{g} \cdot \mathrm{kg}^{-1}\right)$, Trapido (1999) for Estonian soils $\left(12,390 \mu \mathrm{g} \cdot \mathrm{kg}^{-1}\right)$ or 
Wang et al. (2003) for Tianjin soils (812.2 $\left.\mu \mathrm{g} . \mathrm{kg}^{-1}\right)$. Total PAHs concentrations in PEFI are also lower than other urban soils of North Hemisphere. Nadal et al. (2004) found a mean of $736 \mu \mathrm{g} \cdot \mathrm{kg}^{-1}$ in Terragona residential soils, Motelay-Massei et al. (2004) concentration values of $2780 \mu \mathrm{g} \cdot \mathrm{kg}^{-1}$ in Rouen urban soils and Trapido (1999) observed a mean level of $2240 \mu \mathrm{g} \cdot \mathrm{kg}^{-1}$ in Estonian urban soils. These concentrations are, however, similar to the values reported by Yang et al. (2002) for Tokushima urban soils $\left(610.6 \mu \mathrm{g} . \mathrm{kg}^{-1}\right)$ and higher than those found in Bangkok (129.2 $\left.\mu \mathrm{g} \cdot \mathrm{kg}^{-1}\right)$ by Wilcke et al. (1999). For natural soils, the total PAHs concentrations in the current study are similar with those reported by Wilcke et al. (2003) for Amazon soils (145 $\mu \mathrm{g} \cdot \mathrm{kg}^{-1}$ ) and Mata Atlântica soils $\left(115 \mu \mathrm{g} \cdot \mathrm{kg}^{-1}\right)$, as well as to the levels reported by Nadal et al. (2004) for Spanish unpolluted soils $\left(112 \mu \mathrm{g} \cdot \mathrm{kg}^{-1}\right)$ and by Nam et al. (2003) for agricultural soils of Korea (158 $\left.\mu \mathrm{g} \cdot \mathrm{kg}^{-1}\right)$.

Lower accumulations in tropical urban soils compared to temperate urban soils can be related to lower organic matter content. Studies generally reported that PAHs accumulate in organic matter rich horizons because of their affinity with soil organic matter (Krauss et al. 2000, Wilcke 2000). Gaboriau and Saada (2001), when studying PAHs retention by kaolinite, confirmed that composition of organic matter is the primary factor in PHEN retention by the soils. Tropical soils are indeed usually poorer in organic matter when compared with temperate soils. Average organic matter content in the topsoil $20 \mathrm{~cm}$ of the PEFI soil was $2.1 \%$, to be compared to values around $4.0 \%$ for most temperate soils (Brady and Weil 1999). Higher volatilization, lixiviation and degradation, contributing to lower $\Sigma$ PAHs in soils, are also expected in tropical areas, due to higher average temperature and rainfall (Maliszewska-Kordybach 1993, Krauss et al. 2000).

\section{CONCLUSION}

The results showed that the soil of the São Paulo urban area (PEFI) are greatly submitted to anthropogenic emissions and suffer the impact of the city. The PAHs accumulation is characterized by high molecular weight PAHs produced by gasoline and other fossil fuels combustion. Despite the high urbanization of the area, however, the $\Sigma$ PAHs values of the urban soil are relat- ively low with regard to other urban areas under cold or temperate climates. This is likely due to lower retention, because of low organic matter content of the soil, and to higher sink, owing to the higher temperature and rainfall of tropical climate. With regard to natural area (CUNHA), more studies are necessary to provide a minimum knowledge about natural production and PAHs behavior (lixiviation, evaporation, biodegradation, etc.).

\section{ACKNOWLEDGMENTS}

The authors wish to thank the Institute of Forestry for its collaboration in the field work and Prof. Jorge Moreira-Vaz and Prof. Lilian Rotschild Franco de Carvalho for their valuable help in the protocols and analysis of the PAHs. This work was supported by Coordenação de Aperfeiçoamento de Pessoal de Nível Superior - Comitê Francês de Avaliação da Cooperação Universitária e Científica com o Brasil (CAPESCOFECUB) 97.1.27251.1.0 and Fundação de Apoio à Pesquisa do Estado de São Paulo (FAPESP) Project no. 1998/10356-5.

\section{RESUMO}

Estudos sobre a poluição por Hidrocarbonetos Policíclicos Aromáticos (HPAs) são escassos em solos tropicais e no Brasil. Um estudo foi realizado para examinar a composição, as concentrações e fontes de HPAs encontrados em Latossolos vermelho-amarelo (Oxissolos), remanescentes de Mata Atlântica no Estado de São Paulo. As áreas de estudos localizaram-se em um sítio urbano (PEFI) e um natural (CUNHA). A composição granulométrica, $\mathrm{pH}$, teor de matéria orgânica e composição mineralógica foram determinados em amostras de solo superficial. A soma dos HPAs analisados ( $\Sigma$ HPAs) foi 4,5 vezes mais elevada na área urbana do que na área natural. Acenaftileno, acenafteno, fluoreno, fenantreno e fluoranteno foram detectados, em concentrações similares, nos solos das duas áreas. Acenafteno e fluoreno foram os compostos mais abundantes. O pireno foi duas vezes mais abundante no solo da área natural (15 $\left.\mu \mathrm{g} \cdot \mathrm{kg}^{-1}\right)$, e o fluoranteno foi o composto dominante $\left(203 \mu \mathrm{g} \cdot \mathrm{kg}^{-1}\right)$ na área urbana (6,8 vezes mais elevado que na área natural). Alguns compostos de alto peso molecular, traçadores de emissões veiculares, foram detectados em quantidades significativas no solo da área urbana. O pireno representou $79 \%$ da $\Sigma$ HPAs, enquanto que não foi detectado na área natural. Estes resultados evidenciaram que 
os solos de floresta em áreas urbanas são caracterizados pela acumulação de HPAs pesados oriundos de emissões industriais e veiculares.

Palavras-chave: Floresta Atlântica, hidrocarbonetos policíclicos aromáticos, HPAs, floresta tropical, solos tropicais, solos urbanos.

\section{REFERENCES}

Aamot E, Steinnes E And Schmid R. 1996. Polycyclic aromatic hydrocarbons in Norwegian forest soils: impact of long range atmospheric transport. Environ Pollut 92: 275-280.

AZevedo DA, Moreira LS AND Siqueira DS. 1999. Composition of extractable organic matter in aerosols form urban areas of Rio de Janeiro city, Brazil. Atmos Environ 33: 4987-5001.

BRADY NC AND WEIL RR. 1999. The nature and properties of soils. $12^{\text {th }}$ ed., Prentice Hall, New Jersey, 881 p.

Bicudo DC, Forti MC And Bicudo CEM. 2002. Parque Estadual das Fontes do Ipiranga (PEFI): Unidade de Conservação que Resiste à Urbanização de São Paulo, Editora da Secretaria do Meio Ambiente do Estado de São Paulo, São Paulo, Brazil, 351 p.

Bourotte C, Forti MC, Taniguchi S, Bícego MC AND LotUfo PA. 2005. A wintertime study of PAHs in fine and coarse aerosols in São Paulo city, Brazil. Atmos Environ 39: 3799-3811.

CETESB. 2006 Companhia de Tecnologia de Saneamento Ambiental, 2005. Relatório de qualidade do ar no Estado de São Paulo 2005, Report of air quality in the São Paulo State 2006. Cetesb, São Paulo. Available at: $<$ http://www.cetesb.sp.gov.br $>$.

Cicco V, Emmerich W and Fujieda M. 1987. Determinação da curva chave do vertedouro da bacia experimental D do Parque Estadual da Serra do Mar-Núcleo Cunha/SP. Boletim Técnico do Instituto Florestal 42: 79-96.

Daisey JM, Miguel AH, de Andrade JB, Pereira PAP AND TANNER RL. 1987. An overview of the Rio de Janeiro aerosol characterization study. APCA J 37: $15-23$.

FERNANDES MB, BRICKUS LSR, MOREIRA JC AND CARdoso JN. 2002. Atmospheric BTX and polyaromatic hydrocarbons in Rio de Janeiro, Brazil. Chemosphere 47: 417-425.

GABORIAU H AND SAADA A. 2001. Influence of heavy organic pollutants of anthropic origin on $\mathrm{PAH}$ retention by kaolinite. Chemosphere 44: 1633-1639.
Gonzalezvila FJ, Lopez JL, Martin F AND DelRio JC. 1991. Determination in soils of PAHs produced by combustion of biomass under different conditions. Fres J Ana Chem 339: 750-753.

Jenkins BM, Jones AD, TURn SQ And Williams RB. 1996. Particle concentrations, gas-particle partitioning and species intercorrelations for polycyclic aromatic hydrocarbons (PAH) emitted during biomass burning. Atmos Environ 30: 3825-3835.

Krauss M, Wilcke W And Zech W. 2000. Polycyclic aromatic hydrocarbons and polychlorinated biphenyls in forest soils: depth distribution as indicator of different fate. Environ Pollut 110: 79-88.

MaliszewSKA-KoRdyBaCH B. 1993. The effect of temperature on the rate of disappearence of polycyclic aromatic hydrocarbons from soils. Environ Pollut 79: 15-20.

MaliszewsKa-Kordybach B. 1996. Polycyclic aromatic hydroarbons in agricultural soils in Poland: preliminary proposals for criteria to evaluate the level of soil contamination. Appl Geochem 11: 121-127.

Martinis BS, OKamoto RA, Kado NY, Gundel LA AND CARVAlho LRF. 2002. Polycyclic aromatic hydrocarbons in a bioassay-fractionated extract of PM10 collected in São Paulo, Brazil. Atmos Environ 36: 307-314.

Mielke HW, Wang G, Gonzales CR, Powell ET, LE B AND QUACH VN. 2004. PAHs and metals in the soils of inner-city and suburban New Orleans, Louisiana, USA. Environ Toxicol Phar 18: 243-247.

Miguel AH AND ANDRAdE JB. 1989. Rapid quantification of ten polycyclic aromatic hydrocarbons in atmospheric aerosols by direct HPLC separation after ultrasonic acetonitrile extraction. Int J Environ An Ch 35: 35-41.

Miguel AH ANd Pereira PAP. 1989. Benzo(k)fluoranthene, benzo(ghi)perylene, and indeno(1,2,3-cd)pyrene: news tracers of automotive emissions in receptor modeling. Aerosol Sci Tech 10: 292-295.

Motelay-Massei A, Ollivon D, Garban B AND Chevreuil M. 2003. Polycyclic aromatic hydrocarbons in bulk deposition at a suburban site: assessment by principal component analysis of the influence of meteorological parameters. Atmos Environ 37: 3135-3146.

Motelay-Massei A, Ollivon D, Garban B, Teil MJ, Blanchard M and Chevreuil M. 2004. Distribution and spatial trends of PAHs and PCBs in soils in the Seine River basin, France. Chemosphere 55: 555-565.

NADAl M, Schuhmacher M AND Domingo JL. 2004. Levels of PAHs in soils and vegetation samples from Tarragona County, Spain. Environ Pollut 132: 1-11. 
NAm JJ, Song BH, Eom KC, LeE SH And Smith A. 2003. Distribution of polycyclic aromatic hydrocarbons in agricultural soils in South Korea. Chemosphere 50: $1281-1289$

Pathirana S, Connell DW and Vowles PD. 1994. Distribution of polycyclic aromatic hydrocarbons (PAHs) in an urban roadway system. Ecotox Environ Safe 28: 256-269.

Santos CYM, Almeida Azevedo D and Neto FRA. 2002. Selected organic compounds from biomass burning found in the atmospheric particulate matter over sugarcane plantation areas. Atmos Environ 36: 3009-3019.

Struffaldi-De-Vuono Y, Martin-Silveira Lopes MI AND Domingos M. 1984. Poluição atmosférica e elementos tóxicos na reserva biológica do Instituto de Botânica, São Paulo, Brasil. Rev Brasil Bot 7: 149-156.

TRAPIDO M. 1999. Polycyclic aromatic hydrocarbons in Estonian soils: contamination and profiles. Environ Pollut 105: 67-74.

VAsconcellos PC, ZaCARias D, Pires MAF, Pool CS AND CARVALHO LRF. 2003. Measurements of polycyclic aromatic hydrocarbons in airborne particles from the metropolitan area of São Paulo City, Brazil. Atmos Environ 37: 3009-3018.

WANG XJ, Zheng Y, LiU RM, Li BG, CAO J And TAO S. 2003. Kriging and PAH pollution assessment in the topsoil of Tianjin area. B Environ Contam Tox 71: 189-195.
Weiss P, Riss A, GSChMEIDler E AND SChentz H. 1994. Inventory of heavy metals, PAH, PCB patterns and $\mathrm{PCDD} / \mathrm{F}$ profiles of soil samples from an industrialized urban area (Linz, Upper Austria) with multivariate statistical methods. Chemosphere 29: 2223-2236.

Wilcke W. 2000. Polycyclic Aromatic Hydrocarbons (PAHs) in soil - a Review. J Plant Nutr Soil Sc 163: 229-248.

Wilcke W, Muller S, Kanchanakool N, Niamskul C AND ZECH W. 1999. Polycyclic aromatic hydrocarbons (PAHs) in hydromorphic soils of the tropical metropolis Bangkok. Geoderma 91: 297-309.

Wilcke W, Amelung W, Krauss M, Martius C, BanDeIRA A AND Garcia MVB. 2003. Polycyclic aromatic hydrocarbon (PAH) patterns in climatically different ecological zones of Brazil. Org Geochem 34: 1405-1417.

Wilcke W, Krauss M, Lilienfein J and Amelung W. 2004. Polycyclic aromatic hydrocarbon storage in a typical Cerrado of the Brazilian savanna. J Environ Qual 33: 946-955.

Wild SR AND Jones KC. 1995. Polynuclear aromatic hydrocarbons in the United Kingdom environment: a preliminary source inventory and budget. Environ Pollut 88: $91-108$.

YANG Y, Zhang XX AND Korenaga T. 2002. Distribution of polynuclear aromatic hydrocarbons (PAHs) in the soil of Tokushima, Japan. Water Air Soil Poll 138: 51-60. 